\title{
Randomized comparative study of safety and efficacy of oral and vaginal misoprostol in the termination of second trimester pregnancy at tertiary care institution
}

\author{
Lujimmala S., Anitha E.*
}

Department of Obstetrics and Gynecology, Tirunelveli Medical College Hospital, Tirunelveli, Tamil Nadu, India

Received: 25 August 2017

Accepted: 25 September 2017

\section{*Correspondence:}

Dr. Anitha E,

E-mail: eanitha78@gmail.com

Copyright: () the author(s), publisher and licensee Medip Academy. This is an open-access article distributed under the terms of the Creative Commons Attribution Non-Commercial License, which permits unrestricted non-commercial use, distribution, and reproduction in any medium, provided the original work is properly cited.

\begin{abstract}
Background: A prospective randomized study was conducted in 72 pregnant women, with gestational period between 12 and 20 weeks, to compare the efficacy and safety of oral versus vaginal administration of misoprostol for second trimester pregnancy termination. The study was conducted in the Department of Obstetrics and Gynaecology, Government Kilpauk Medical College and Hospital (KMCH), Chennai, South India from November 2012 and November 2013.

Methods: Women aged 18-38 years requesting MTP for maternal reason, foetal congenital anomalies and intrauterine foetal demise were randomly assigned into two groups. Group A $(n=36)$ had misoprostol orally while the Group B $(n=36)$ received misoprostol by vaginal route. Dosage regimen was similar in both the groups that was $200 \mu \mathrm{g}$ every 4 hrs until the abortion occurred, maximum up to 6 doses. Efficacy included induction to delivery interval and safety included maternal complications and side-effects like nausea, vomiting, diarrhoea, fever and abdominal pain and results were compared.

Results: The percentage of women who delivered was significantly higher in the vaginal group than the oral group $(94.44 \%$ versus $66.67 \%, \mathrm{P}<0.03018)$ within 24 hours. The induction to delivery interval and incidence of side-effects were noted.

Conclusions: Vaginal administration of misoprostol resulted in a higher success rate and misoprostol is safe and effective drug for second trimester pregnancy termination.
\end{abstract}

Keywords: Misoprostol, Oral route, Second trimester pregnancy termination, Vaginal route

\section{INTRODUCTION}

Abortion is theoretically defined as termination of pregnancy before the foetus becomes viable (capable of living independently). This has been fixed administratively at 28 weeks, when the foetus weighs approximately $1000 \mathrm{~g}$. Medical abortion has become extremely popular today. The accepted method of medical abortion worldwide is a combination of Mifepristone with the prostaglandin. Unsafe abortion resulting in complications are main public health problems in developing countries. Abortion is legal for a wide range of medical and social reasons in our country.

Khan et al in his study observed that problems such as abortion services by trained medical personnel in registered facilities, the stigma connected with induced abortion, the threat of forced contraceptive acceptance, and low levels of awareness regarding the legality of the procedure compel them to undergo illegal abortion under untrained practitioners using unsafe conditions resulting in chronic reproductive tract morbidity such as chronic 
disability, infertility and infections. ${ }^{1}$ According to the Consortium on National Consensus for Medical Abortion in India, every year an average of about 11 million pregnancies are terminated by medical ground and 20,000 women died every year due to abortion-related complications. ${ }^{2}$ Most abortion-related maternal deaths are attributable to illegal abortions. Worldwide 42 million legal abortions and 10 to 12 million clandestine abortion take place every year, of which 10 to $15 \%$ is performed in second trimester. In India alone, 6.7 million induced abortions occur annually, of which late abortion constitute 7 to $15 \% .^{3}$

Methods of second trimester MTP include surgical evacuation, medical methods, extra ovular instillation of drugs and extra uterine methods. The above methods are used singly or in combination. The second trimester abortion is associated with more risks than a first trimester procedure and hence should not be undertaken lightly. According to the MTP act 1971 of India, opinion of two registered medical practitioners is essential before performing a second trimester abortion. An ultrasound is a good prerequisite specially to confirm and document the gestational age. The upper limit is 20 weeks. The incidence of second trimester MTP has drastically come down and is mainly employed today for foetal malformations.

Misoprostol is a synthetic analogue of prostaglandin E1. It is an important drug in Obstetrics and Gynaecology practices because of its priming action on uterus and cervix. The clinical application of misoprostol includes medical abortion, induction of labor, cervical priming before surgical procedure, medical evacuation for miscarriages and management of postpartum haemorrhage. Misoprostol is available in many countries worldwide and has advantages over the rest of the prostaglandins as it is inexpensive, thermo and light stable and has shelf life of several years even in tropical conditions and is easy to use. Its action upon the contractility of myometrium is extensive and is very efficient in dilating the cervix. It can be used alone or with combination of Mifepristone. The routes of administration of Misoprostol are oral, buccal, sublingual, vaginal and rectal. The most common sideeffects after administration of misoprostol are vomiting, abdominal pain, headache, chills, fever, shivering and diarrhea.

Considering the merits of misoprostol and its beneficial effect on uterus and cervix to expel the foetus under MTP, the present study was under taken in the Department of Obstetrics and Gynaecology, Government Kilpauk Medical College Hospital, Chennai, South India with the following objectives: 1 . To compare the efficacy and safety of both oral and vaginal misoprostol in second trimester pregnancy termination. 2. To study the induction-abortion interval with misoprostol by oral and vaginal route.

\section{METHODS}

Present study was a randomized prospective study of seventy-two healthy women, between age 18 and 38 years, with 12-20 weeks of pregnancy, requesting second trimester termination of pregnancy, were admitted in Department of Obstetrics and Gynecology, Kilpauk Medical College, a tertiary medical college in south India. The study was conducted between November 2012 and November 2013.

For a confidence limit of $95 \%$ the sample size is 64 , hence the sample size was selected as 72 .

\section{Selection of cases}

Seventy-two healthy women, between age 18 and 38 years, with 12-20 weeks of pregnancy, requesting second trimester termination of pregnancy, were included in this study. The indications for termination were in consonance with the MTP Act. Written informed consent was taken from all the women. Sonography was done in women whenever necessary for deciding maturity of the fetus. Ethical clearance was obtained from the hospital ethical committee.

\section{Exclusion criteria}

Include women with baseline hemoglobin less than 8 $\mathrm{gm} / \mathrm{dl}$, maternal local or systemic infection, maternal respiratory disease, liver or kidney disease, Cardio vascular disease, severe bronchial asthma, chronic adrenal failure or steroid therapy and uncontrolled seizure disorder. The investigations complete blood count, renal function tests, urine routine, blood group, ultra-sonogram, bleeding time and clotting time, VDRL, HIV, HBSAg were done prior to misoprostol administration.

\section{Study group}

The patients were randomly allocated to Group A $(n=36)$ who received oral tablet misoprostol and Group B $(n=36)$ who received vaginal tablet misoprostol. A total of 72 cases between 12 and 20 gestational weeks who had undergone for medical abortion by using the defined misoprostol regime were included in the study. The misoprostol regimes were given in the hospital. The

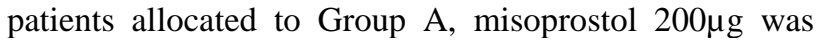
given orally every 4 hours until the abortion occurred or maximum up to 6 doses. Doses administered through the oral route were observed. The expulsion rate of this regimen at different time intervals ( $<24$ hours (4-6 hours, 6-8 hours, 8-10 hours, 10-12 hours, 12-16 hours and 1624 hours) and <48 hours) and complications were investigated. The incidence of side-effects, vital signs, amount of bleeding and uterine contractions were investigated every 3 hours. The pelvic examination was done every 3 hours. The gestational weeks of the patient were calculated based on the first day of the last menstrual period. The calculated gestational weeks were 
confirmed with ultra-sonography. A second course of misoprostol was administered if abortion did not happen after 24 hours.

For patients in Group B, misoprostol $200 \mu \mathrm{g}$ were vaginally administered every 4 hours till the expulsion of fetus or up to a maximum of 6 doses. Doses administered through the vaginal route were noted. Vaginal misoprostol was soaked in saline solution and administered to the posterior fornix and intra cervical region. The management and observation of the subjects were followed as in case of the procedure followed for Group A.

Information about side effects was taken from each woman including nausea, vomiting, diarrhea, fever and abdominal pain. The expulsion rates were evaluated at the $<24$ hours and $<48$ hours. After the abortion process was complete, per vaginal examination and ultrasonography was done to rule out any retained products and confirm the completion. All the women were kept in hospital for 24 hours under observation. Those who were willing for permanent sterilization were considered for tubal ligation. On discharge they were asked to come for follow-up after a week or earlier if need arises. On follow up, a pelvic examination was performed on all the women. Any abnormal bleeding or delayed side effects were also enquired.

The induction-expulsion (abortion) interval was defined as "the interval between the time of administration of the first dose of misoprostol to the time when the fetus aborted". The complete abortion was defined if fetus and placenta was expelled completely without resorting to further surgical or medical means. The rates of successful abortion after initial misoprostol administration, induction-expulsion interval, the incidence of side effects and complete abortion in both the groups, oral and vaginal were tabulated and compared. The results were statistically analyzed and evaluated using Fisher's exact test (Open Epiprogramme, Version 2.3, 2009).

\section{RESULTS}

A total of 72 women with gestation between 12 and 20 week who needed second trimester termination of pregnancy, were included in the present study. The two groups of 36 women each were compared for various characteristics such as age, parity, previous MTP and LSCS and duration of amenorrhea.

\section{Age distribution of pregnant women}

Table 1 shows age distribution of pregnant women in the age group ranged from 18 to 38 years. The maximum number of women was found in the age group 26-30 $(41.6 \%)$ and $21-25(44.4 \%)$ for oral (Group A) and vaginal (Group B) route of administration, respectively. The minimum number of women was seen in the age group $>35$ years $(2.7 \%)$ both for oral and vaginal route of administration. The mean age of women was 26.13 years for Group A and 25.15 years for Group B.

Table 1: Age distribution of pregnant women.

\begin{tabular}{|lll|}
\hline Age in years & $\begin{array}{l}\text { Group A } \\
(\mathrm{n}=36) \text { number } \\
(\%)\end{array}$ & $\begin{array}{l}\text { Group B } \\
(\mathrm{n}=36) \\
(\%)\end{array}$ \\
\hline$<20$ & $03(8.3 \%)$ & $04(11.1 \%)$ \\
\hline $21-25$ & $13(33.3 \%)$ & $16(44.4 \%)$ \\
\hline $26-30$ & $15(41.6 \%)$ & $13(33.3 \%)$ \\
\hline $31-35$ & $04(11.1 \%)$ & $02(5.5 \%)$ \\
\hline$>35$ & $01(2.7 \%)$ & $01(2.7 \%)$ \\
\hline Mean age (years) & 26.13 & 25.15 \\
\hline
\end{tabular}

\section{Demographic data of pregnant women}

Table 2 shows that the maximum number of women was multiparous $77.7 \%$ for Group A and $66.6 \%$ for Group B. The number of women who had previous MTP for Group $\mathrm{A}$ and Group B was found to be $11.11 \%$ and $8.3 \%$, respectively. In Group A only one woman (2.7\%) was found to have undergone LSCS. As shown in Table 3 the maximum number of women was found to be $11(30.5 \%)$ in the gestation period 12-14 weeks and $11(30.5 \%)$ in the period of gestation 14-16 weeks for Group A and Group $\mathrm{B}$, respectively.

Table 2: Demographic profile of pregnant women.

\begin{tabular}{|lll|}
\hline Parameter & Parity No. (\%) & Parity No. (\%) \\
\hline Primi & $08(22.2 \%)$ & $12(33.3 \%)$ \\
\hline Multi & $28(77.7 \%)$ & $24(66.6 \%)$ \\
\hline Previous MTP & $04(11.11 \%)$ & $03(8.3 \%)$ \\
\hline Previous LSCS & $01(2.7 \%)$ & $0(0 \%)$ \\
\hline
\end{tabular}

Table 3: Period of gestation of pregnant women.

\begin{tabular}{|lll|}
\hline Weeks & $\begin{array}{l}\text { Group A }(\mathbf{n}=36) \\
\text { Number }(\%)\end{array}$ & $\begin{array}{l}\text { Group B (n=36) } \\
\text { Number }(\%)\end{array}$ \\
\hline $12-14$ & $11(30.5 \%)$ & $10(27.7 \%)$ \\
$14-16$ & $09(25.0 \%)$ & $11(30.5 \%)$ \\
\hline $16-18$ & $09(25.0 \%)$ & $09(25.0 \%)$ \\
\hline $18-20$ & $07(19.4 \%)$ & $06(16.6 \%)$ \\
\hline $\begin{array}{l}\text { Mean gestation } \\
\text { age (weeks) }\end{array}$ & 15.66 & 15.61 \\
\hline
\end{tabular}

Table 4 and 5 show the relationship of induction-abortion interval to the gestational age. Most of the women aborted between 6 and 8 hours (36.0\%) for oral misoprostol Group A and $25 \%$ for vaginal misoprostol Group B for 12-16 weeks gestational age.

For the gestational age of 16-20 weeks, the maximum number of induced abortion between 6-8 hours was found to be $13.8 \%$ and $16.6 \%$ for oral misoprostol (Group A) and vaginal misoprostol (Group B), respectively. 
The mean induction abortion interval (for 12-16 weeks) for Group A and Group B was 10.05 and 9.05 hours respectively.
The mean induction-abortion interval for 16-20 weeks for Group A and Group B was 12.43 hours and 12.52 hours respectively.

Table 4: Induction-abortion interval of oral misoprostol (Group A).

\begin{tabular}{|c|c|c|c|c|c|c|c|c|}
\hline \multirow{2}{*}{ Weeks } & \multicolumn{6}{|l|}{$<24$ hours } & \multirow{2}{*}{$<48$ hours } & \multirow[b]{2}{*}{ Total } \\
\hline & 4-6 hours & 6-8 hours & 8-10 hours & 10-12 hours & 12-16 hours & 16-24 hours & & \\
\hline $\begin{array}{l}12-16 \\
\text { Group A }\end{array}$ & 1 & 6 & 4 & 0 & 2 & 1 & 4 & $18+(2)^{*}$ \\
\hline $\begin{array}{l}16-20 \\
\text { Group A }\end{array}$ & 0 & 5 & 3 & 1 & 2 & 1 & 4 & $14+(2)^{*}$ \\
\hline
\end{tabular}

*Two women each in 12-16 and 16-20 gestation period under Group A did not abort. Extra vaginal misoprostol dose was given to make the termination complete.

Table 5: Induction-abortion interval of vaginal misoprostol (Group B).

\begin{tabular}{|c|c|c|c|c|c|c|c|c|}
\hline \multirow{2}{*}{ Weeks } & \multicolumn{6}{|l|}{$<24$ hours } & \multirow{2}{*}{$\begin{array}{l}<48 \\
\text { hours }\end{array}$} & \multirow{2}{*}{ Total } \\
\hline & 4-6 hours & 6-8 hours & 8-10 hours & 10-12 hours & 12-16 hours & 16-24 hours & & \\
\hline $\begin{array}{l}\text { 12-16 } \\
\text { Group B }\end{array}$ & 1 & 9 & 5 & 1 & 2 & 0 & 1 & 19 \\
\hline $\begin{array}{l}16-20 \\
\text { Group B }\end{array}$ & 0 & 7 & 3 & 2 & 3 & 1 & 1 & 17 \\
\hline
\end{tabular}

\section{Statistical analysis}

The induction-abortion rate was calculated for Group A and B for gestation of 12-16 and 16-20 weeks within 24 hours and $<48$ hours by statistical analysis. The values are given in the Table 6 and 7.

Table 6: Induction to expulsion interval for 12-16 gestation weeks.

\begin{tabular}{|l|l|l|}
\hline $\begin{array}{l}\text { Time } \\
\text { (hours) }\end{array}$ & $\begin{array}{l}\text { Frequency of } \\
\text { (Group A) }\end{array}$ & $\begin{array}{l}\text { Frequency of } \\
\text { (Group B) }\end{array}$ \\
\hline$<24$ hours & $14(70 \%)$ & $18(94.73 \%)$ \\
\hline$<48$ hours & $4(20 \%)$ & $1(5.26 \%)$ \\
\hline Total & 18 & 19 \\
\hline (P $<0.05)$ Fisher exact 2-tailed test, P value $=0.3061$ \\
\hline
\end{tabular}

$(\mathrm{P}<0.05)$ Fisher exact 2-tailed test, $\mathrm{P}$ value $=0.3061$

Table 7: Induction to expulsion interval for 16-20 gestation weeks.

\begin{tabular}{|lll|}
\hline $\begin{array}{l}\text { Time } \\
\text { (hours) }\end{array}$ & $\begin{array}{l}\text { Frequency of } \\
\text { (Group A) }\end{array}$ & $\begin{array}{l}\text { Frequency of } \\
\text { (Group B) }\end{array}$ \\
\hline$<24$ hours & $10(62.5 \%)$ & $16(94.12 \%)$ \\
\hline$<48$ hours & $4(25.0 \%)$ & $1(5.88 \%)$ \\
\hline Total & 14 & 17 \\
\hline (P $<0.05)$ & Fisher exact 2-tailed test, P value $=0.2239$ \\
\hline
\end{tabular}

Since the cell values obtained for Group A and B for gestation of 12-16 and 16-20 (weeks) within 24 hours and within 48 hours were less than 5 and the values in Table No. 6 and 7 were grouped into a single value. The values are given in the Table 8 . The number of women (in percentage) who aborted in the vaginal group was significantly higher than the oral group. It is to be noted that the success rate of group A was $66.67 \%$ and that of group B was $94.44 \%$ within 24 hours. The induction to expulsion rate in the vaginal group was significantly higher than that in the oral misoprostol group (P $<0.03018$ ).

Table 8: Induction to expulsion interval for oral and vaginal groups.

\begin{tabular}{|lll|}
$\begin{array}{l}\text { Time } \\
\text { (hours) }\end{array}$ & $\begin{array}{l}\text { Oral } \\
\text { misoprostol } \\
\text { Group A }(\mathrm{n}=36)\end{array}$ & $\begin{array}{l}\text { Vaginal } \\
\text { misoprostol } \\
\text { Group B }(\mathbf{n = 3 6})\end{array}$ \\
\hline$<24$ hours & $24(66.67 \%)$ & $34(94.44 \%)$ \\
\hline$<48$ hours & $8(22.21 \%)$ & $2(5.56 \%)$ \\
\hline Total & $32(4 *)$ & 36 \\
\hline
\end{tabular}

$(\mathrm{P}<0.05)$ Fisher exact 2-tailed, $\mathrm{P}$ value $<0.03018$ Statistically significant between the groups; *Two women each women in 12-16 and 16-20 gestation period under Group A did not abort. Extra vaginal misoprostol dose was given to make the termination complete.

Table 9 shows the rate of side effects after administration of misoprostol. After misoprostol administration, the women were observed hourly for side effects, onset of bleeding and vitals. Maximum number of women had nausea $(22.2 \%$ and $36.1 \%$ ) for oral misoprostol group (Group A) and vaginal misoprostol groups (Group B), respectively. The percentage of women who had abdominal pain was found to be 30.5 and 33.3 for oral misoprostol group (Group A) and vaginal misoprostol groups (Group B), respectively. Maximum number of women $(33.3 \%)$ had temperature $>380 \mathrm{C}$ in oral misoprostol group (Group A), whereas in vaginal 
misoprostol group (group B), it was only $11.1 \%$. Sideeffects such as vomiting, diarrhoea, dizziness, headache, breast tenderness and rash were not significant in both the groups.

In the present study, no women had to undergo medical termination of pregnancy by surgical treatment. No severe complications such as heavy bleeding or uterine rupture even in women with previous caesarean delivery history were noticed.

Table 9: Side effects after misoprostol administration.

\begin{tabular}{|lll|}
\hline Parameter & $\begin{array}{l}\text { Oral misoprostol } \\
\text { Group A }(\mathbf{n = 3 6})\end{array}$ & $\begin{array}{l}\text { Vaginal } \\
\text { misoprostol } \\
\text { Group B (n=36) }\end{array}$ \\
\hline Nausea & $8(22.2 \%)$ & $13(36.1 \%)$ \\
\hline Vomiting & $1(2.7 \%)$ & $0(0 \%)$ \\
\hline Diarrhoea & $0(0 \%)$ & $0(0 \%)$ \\
\hline Dizziness & $1(2.7 \%)$ & $0(0 \%)$ \\
\hline Headache & $1(2.7 \%)$ & $0(0 \%)$ \\
\hline $\begin{array}{l}\text { Breast } \\
\text { tenderness }\end{array}$ & $3(8.3 \%)$ & $2(5.5 \%)$ \\
\hline $\begin{array}{l}\text { Lower } \\
\text { abdominal } \\
\text { pain }\end{array}$ & $10(27.7 \%)$ & $12(33.3 \%)$ \\
\hline $\begin{array}{l}\text { Temperature } \\
>38^{\circ} \mathrm{C}\end{array}$ & $11(30.5 \%)$ & $4(11.1 \%)$ \\
\hline Rash & $1(2.7 \%)$ & $0(0 \%)$ \\
\hline
\end{tabular}

Table 10: Labour induction results in two groups.

\begin{tabular}{|lll|}
\hline Parameters & $\begin{array}{l}\text { Oral } \\
\text { misoprostol } \\
\text { Group A }(\mathrm{n}=36)\end{array}$ & $\begin{array}{l}\text { Vaginal } \\
\text { misoprostol } \\
\text { Group B (n=36) }\end{array}$ \\
$\begin{array}{lll}\text { Complete } \\
\text { expulsion }(\%)\end{array}$ & $88.8(\mathrm{n}=32)$ & $100(\mathrm{n}=36)$ \\
\hline $\begin{array}{l}\text { Side-effects } \\
\text { (average \%) }\end{array}$ & 11.6 & 9.5 \\
\hline $\begin{array}{l}\text { Pharmacological } \\
\text { management of } \\
\text { side-effects }(\%)\end{array}$ & $14.0(\mathrm{n}=5)$ & $14.0(\mathrm{n}=5)$ \\
$\begin{array}{l}\text { Manual extraction } \\
\text { placenta }(\%)\end{array}$ & $8.3(\mathrm{n}=3)$ & 0 \\
\hline
\end{tabular}

\section{DISCUSSION}

In the present study out of 122 second trimester pregnant women, 101 were eligible as per the inclusion and exclusion criteria. Out of 101 eligible, a total of 72 pregnant women of $>12$ and $<20$ weeks were randomly selected for two groups (Group A and B) of study. Group A $(n=36)$ comprising of 36 women were given tablet misoprostol $200 \mu \mathrm{g}$ orally every 4 hours until the abortion occurred or maximum up to 6 doses. Women in Group B $(n=36)$ were given vaginal misoprostol $200 \mu \mathrm{g}$ every 4 hours till the expulsion of fetus or up to a maximum of 6 doses. The age distribution and demographic profile of women, induction-abortion interval, incidence of side effects after administration of Misoprostol in Group A and B were analyzed.

The comparative analysis for the Group A and B was made to evaluate the efficacy of misoprostol by oral and vaginal route of administration. The vaginal misoprostol was found to be $100 \%$ effective in complete expulsion of fetus, whereas in oral, the termination of pregnancy was complete only in $88.8 \%$ of women.

The remaining $(11.2 \%)$ women were given additional dose of vaginal misoprostol to complete termination. The success rate of group A was $66.67 \%$ and that of group B was $94.44 \%$ within 24 hours. The induction to expulsion rate (success rate) in the vaginal group was significantly higher than that in the oral misoprostol group ( $\mathrm{P}$ $<0.03018)$. The side-effects due to oral misoprostol $(11.6 \%)$ were more than using vaginal misoprostol $(9.5 \%)$. In case of oral misoprostol $(8.3 \%)$ the placenta had to be extracted manually. However, in case of vaginal route, no such complication was noticed.

Bebbington et al used misoprostol orally and vaginally for mid trimester of pregnancy. ${ }^{4}$ According to their results, significantly more patients were delivered in vaginal group within 24 hours (85.50 versus $9.50 \%$ ). Behrashi $\mathrm{M}$ et al observed in their study that the delivery percentage of vaginal group was significantly higher than oral group (86.7 versus $43.30, \mathrm{p}$ value is 0.0006$).{ }^{5}$ The results obtained in this study are similar or comparable to the findings in literature. The success rate was found to be $89 \%$ within 24 hours when a regime of $200 \mu \mathrm{g}$ misoprostol was given vaginally at every 12 hours (Jain and Mishell). ${ }^{6}$

Nuutila et al, in their study noticed that $200 \mu \mathrm{g}$ of vaginal administration of misoprostol resulted in abortion rates of $40 \%$ and $92 \%$, in 24 and 48 hours respectively. ${ }^{7}$ In another study conducted by Prachasilpchai et al, $400 \mu \mathrm{g}$ intra vaginal misoprostol was administered every 12 hours. ${ }^{8}$

The success rate over 48 hours was found to be $89.4 \%$ and the mean expulsion time was found to be $17.07 \pm 9.96$ hours. Both the success rate over 48 hours and the mean expulsion time were similar to those of the present study. Sumant SR et al in their study to find out the safety and effectiveness of vaginal misoprostol for second trimester termination of pregnancy concluded that vaginal misoprostol is a very effective and safe method for second trimester pregnancy termination. ${ }^{9}$

In this study, the most common side effects were observed. After misoprostol administration, the women were monitored hourly for vitals, side effects and onset of bleeding. Maximum number of women had nausea (22.2\% and $36.1 \%$ ) for oral misoprostol group (group A) and vaginal misoprostol groups (group B), respectively. The percentage of women who had abdominal pain was found to be $27.7 \%$ and $33.3 \%$ for oral misoprostol group 
(group A) and vaginal misoprostol groups (group B), respectively.

Maximum number of women (30.5\%) had temperature $>38^{\circ} \mathrm{C}$ in oral misoprostol group (group A), whereas in vaginal misoprostol group (group B), it was only $11.1 \%$. Side-effects such as vomiting, diarrhoea, dizziness, headache, breast tenderness and rash were not significant in both the groups.

A median dose of about $1000 \mu \mathrm{g}$ produced vomiting $(57 \%)$ and diarrhoea $(29 \%)$ in their study of El-Refaey and Templeton. ${ }^{10}$ The incidence of side effects was not truly associated to total amount of misoprostol used. They also observed that side effect of fever was found to be $32.4 \%$ and $12.2 \%$ in the group 1 and group 2, respectively.

Javed et al reported nausea and vomiting in $4 \%$ of the vaginal protocol of the study subjects. ${ }^{11}$ Nausea and vomiting was much higher in the study of Iqbal, in addition to headache, fever and chills, reason of which could be comparatively higher dose (Iqbal et al). ${ }^{12}$

Dickinson et al also noticed more side effects with higher dosage of vaginal misoprostol, while Kamal et al reported no significant difference between side effects of misoprostol while comparing vaginal with oral route..$^{13,14}$ The side-effects such as fever $(24.5 \%)$, abdominal pain $(16 \%)$, nausea and vomiting $(5.3 \%)$ were noticed (Prachasilpchai et al). ${ }^{8}$

Behrashi M and Mahdian M noticed in their study that in vaginal misoprostol group, fever was the most complication $(20 \%)$ and in oral group shivering (33\%) and fever $(20 \%)$ were the most complained. ${ }^{5}$ Neither of the women in both groups had abdominal pain, vomiting or diarrhoea as a side-effect of therapy. Severe complications such as uterine perforation and heavy bleeding have not been seen in both groups of study.

In the literature, apart from pain, the side effects of misoprostol are usually mild and self-limited (Wildschut et al). ${ }^{15}$ In this study, except for pain, complication rates were low and other complications except nausea were self-limited. Half of the cases were given antiemetic medications for nausea.

\section{CONCLUSION}

In conclusion, the present research study reveals that vaginal misoprostol administration was found to be superior, more effective and efficacious in second trimester pregnancy termination than the oral administration due to the achievement of complete termination within 48 hours. Shorter hospital stay and less expenditure are the advantages of vaginal misoprostol administration. This effect is due to improved pharmacokinetics associated with vaginal administration. Moreover, the side-effects noticed after vaginal misoprostol administration were minimal compared to oral misoprostol administration. In case of oral misoprostol administration for some women additional dose of vaginal misoprostol administration was warranted. It is therefore, recommended that for the second trimester termination pregnancy, it is preferable to use vaginal misoprostol administration.

Funding: No funding sources

Conflict of interest: None declared

Ethical approval: The study was approved by the Institutional Ethics Committee

\section{REFERENCES}

1. Khan ME, Barge S, Kumar N, Almroth S. Abortion in India: current situation and future challenges. In: Pachuri S, Subramaniam S, eds. Implementing a Reproductive Health Agenda in India: The Beginning. 1st ed. New Delhi: Population Council Regional Office; 1998:507-529.

2. Consortium on National Consensus for Medical Abortion in India. New Delhi: Consortium on National Consensus for Medical Abortion in India. Available

at http://www.aiims.edu/aims/events/Gynaewebsite/ma _finalsite/introduction.html. Accessed 3 Dec 2008.

3. Robert Johnston. Wm. Historical abortion statistics, India. 2013.

4. Bebbington MW, Kent N, Lim K, Gagnon A, Delisle MF, Tessier F, et al. A randomized controlled trail comparing two protocols for the use of misoprostol in mid-trimester pregnancy termination. Am J Obstet Gynecol. 2002; 187:853-7.

5. Behrashi M, Mahdian M. Vaginal versus oral misoprostol for second-trimester pregnancy termination: a randomized trial. Pak J Biol Sci. 2008;11(21):2505-8.

6. Jain JK, Mishell DR Jr. A comparison of intravaginal misoprostol with prostaglandin E2 for termination of second trimester pregnancy. $\mathrm{N}$ Eng $\mathrm{J}$ Med. 1994;331:290-3.

7. Nuutila M, Toivonen J, Ylikorkala $\mathrm{O}$, Halmesmäki E. A comparison between two doses of intra vaginal misoprostol and gemeprost for induction of second trimester abortion. Obstet Gynecol. 1997;90:896900.

8. Prachasilpchai N, Russameecharoen K, Borriboonhirunsarn D. Success rate of secondtrimester termination of pregnancy using misoprostol. J Med Assoc Thai. 2006;89:1115-9.

9. Shah SR, Tripathi JB, Suthar HD, Modi KJ, Astik JK, Bhuria DJ. Role of vaginal misoprostol in second trimester termination of pregnancy. J Obstet Gynecol Ind. 2010;60(2):146-8.

10. El Refaey H, Templeton A. Induction of abortion in the second trimester by a combination of misoprostol and mifepristone -a randomized comparison between two misoprostol regimens. Hum Reprod. 1995;10:475-8. 
11. Javed L, Malik M, Jamal N, Sheikh S, Farzana F. Mid-trimester termination of pregnancy-comparison of sublingual with vaginal misoprostol. Biomedica. 2004;20:56-9.

12. Iqbal R, Yaqoob S, Khan F. A comparison of oral and vaginal misoprostol in $2^{\text {nd }}$ trimester termination of pregnancy. JFJMC. 2007;1:70-2.

13. Dickinson JE, Evans SF. A comparison of oral misoprostol with vaginal misoprostol administration in second trimester pregnancy termination for fetal abnormality. Obstet Gynecol. 2003;101:1294-9.

14. Kamal R, Parveen F, Mazhar B. Role of misoprostol in vaginal versus double oro vaginal route for termination of pregnancy in mid-trimester pregnancy. Ann Pak Inst Med Sci. 2005;1:196-200.

15. Wildschut H, Both MI, Medema S, Thomee E, Wildhagen MF, Kapp N. Medical methods for midtrimester termination of pregnancy. Cochrane Database Syst Rev. 2011;19:CD005.

Cite this article as: Lujimmala S, Anitha E.

Randomized comparative study of safety and efficacy of oral and vaginal misoprostol in the termination of second trimester pregnancy at tertiary care institution. Int J Reprod Contracept Obstet Gynecol 2017;6:5018-24. 